\title{
Pressure Immobilization After North American Crotalinae Snake Envenomation
}

\author{
American College of Medical Toxicology • \\ American Academy of Clinical Toxicology • \\ American Association of Poison Control Centers • \\ European Association of Poison Control Centres • \\ International Society of Toxinology • \\ Asia Pacific Association of Medical Toxicology
}

Published online: 8 November 2011

(C) This Position Statement is being published without copyright 2011

Keywords Crotalinae $\cdot$ Snake envenomation $\cdot$ Pressure immobilization $\cdot$ First aid $\cdot$ Snake bite

\section{Background}

The vast majority of venomous snake bites treated at health care facilities in the United States of America each year involve nonneurotoxic Crotalinae species [1]. Large case series reveal the major clinical effect associated with these envenomations to be local tissue injury. Extremity swelling and dermonecrosis are common, with compartment syndrome as an infrequent but potentially limb-threatening effect of envenomation [2-5]. Life-threatening systemic toxicity and death are rare.

Historically, many first aid measures have been employed in the treatment of snake bites, but none have been shown to improve patient outcome. Pressure immobilization is a technique routinely employed in the prehospital management of neurotoxic snake species in Australia. First described by Sutherland and colleagues in the 1970s, pressure immobilization involves wrapping the entire extremity with a bandage and then immobilizing the extremity with a splint [6]. The bandage should generate a pressure between 40 and $70 \mathrm{mmHg}$ in the upper extremity and 55 and $70 \mathrm{mmHg}$ in

This position statement is being published jointly and simultaneously with Clinical Toxicology and will appear in their December 2011 print issue.

American College of Medical Toxicology

10645 N. Tatum Blvd. Suite 200-111,

Phoenix, AZ 85028, USA

e-mail: jmt@acmt.net the lower extremity in order to effectively delay systemic absorption of venom [7].

Several animal studies have demonstrated delayed systemic absorption of venom with pressure immobilization [6-8]. However, studies have also revealed that pressure immobilization bandages are commonly applied incorrectly, even in a simulated setting following provider instructions and training [9-12]. Although the more common error is to apply the bandage too loosely, when applied too tightly, the bandage may function as a tourniquet, causing limb ischemia, and may also increase systemic absorption of the venom [7].

Animal models of North American Crotalinae envenomation demonstrate delayed systemic absorption of venom and delayed mortality following application of pressure immobilization bandages [13-15]. However, the local effects of sequestering cytotoxic venom in the extremity are less clear. In a swine model of pressure immobilization following Crotalus atrox lower extremity envenomation, intracompartmental pressure increased significantly compared to controls, from a nonsurgical range to levels that would prompt fasciotomy [13].

\section{Position}

Given that the primary toxic effect of envenomation is local tissue injury, mortality is not an ideal outcome measure to extrapolate to human crotaline envenomation. Available evidence fails to establish the efficacy of pressure immobilization in humans, but does indicate the possibility of serious adverse events arising from its use. The use of pressure immobilization for the prehospital treatment of 
North American Crotalinae envenomation is not recommended.

Acknowledgments The organizations acknowledge the efforts of Michael Levine, MD and Michelle Ruha, MD in creating this position statement.

\section{References}

1. Bronstein AC, Spyker DA, Cantilena LR Jr et al (2010) 2009 Annual report of the American Association of Poison Control Centers' National Poison Data System (NPDS): 27th annual report. Clin Toxicol 48:979-1178

2. Corneille MG, Larson S, Stewart RM et al (2006) A large singlecenter experience with treatment of patients with crotalid envenomations: outcomes with and evolution of antivenin therapy. Am J Surg 192(6):848-852

3. Spiller HA, Bosse GM (2003) Prospective study of morbidity associated with snakebite envenomation. J Toxicol Clin Toxicol 41(2):125-130

4. Tanen D, Ruha AM, Graeme K, Curry S (2001) Epidemiology and hospital course of rattlesnake envenomations cared for at a tertiary referral center in central Arizona. Acad Emerg Med 8 (2):177-182

5. Thorson A, Lavonas EJ, Rouse AM, Kerns WP (2003) Copperhead envenomations in the Carolinas. J Toxicol Clin Toxicol 41 (1):29-35

6. Sutherland SK, Coulter AR, Harris RD (1979) Rationalisation of first-aid measures for elapid snakebite. Lancet 27:183-185
7. Howarth DM, Southee AE, Whyte IM (1994) Lymphatic flow rates and first-aid in simulated peripheral snake or spider envenomation. Med J Aust 161:695-700

8. German BT, Hack JB, Brewer K et al (2005) Pressureimmobilization bandages delay toxicity in a porcine model of eastern coral snake (Micrurus fulvius fulvius) envenomation. Ann Emerg Med 45:603-608

9. Canale E, Isbister GK, Currie BJ (2009) Investigating pressure bandaging for snakebite in a simulated setting: bandage type, training, and the effect of transport. Emerg Med Australas 21:184-190

10. Currie BJ, Canale E, Isbister GK (2008) Effectiveness of pressureimmobilization first aid for snakebite requires further study. Emerg Med Australas 20:267-270

11. Norris RL, Ngo J, Nolan K et al (2005) Physicians and lay people are unable to apply pressure immobilization properly in a simulated snakebite scenario. Wilderness Environ Med 16:16-21

12. Simpson IK, Tanwar PD, Chittaranjan A et al (2008) The Ebbinghaus retention curve: training does not increase the ability to apply pressure immobilization in simulated snake biteimplications for snake bite first aid in the developing world. Trans R Soc Trop Med Hyg 102(5):451-459

13. Bush SP, Green SM, Laack TA et al (2004) Pressure immobilization delays mortality and increases intracompartmental pressure after artificial intramuscular rattlesnake envenomation in a porcine model. Ann Emerg Med 44:599-604

14. Meggs WJ, Courtney C, O'Rourke D et al (2010) Pilot studies of pressure-immobilization bandages for rattlesnake envenomations. Clin Toxicol 48:61-63

15. Sutherland SK, Coulter AR (1981) Early management of bites by the eastern diamondback rattlesnake (Crotalus adamanteus): studies in monkeys (Macaca fascicularis). Am J Trop Med Hyg 30:497-200 